\title{
胆汁より單離せられた一種の鉄化合物の 医化学的性質に就いて
}

\section{第二報 胆汁分泌促進作用}

\author{
日本大学蔽学部理工学教室 (主任 早川堅太郎教授) \\ 中島隆治荒木良二小池正雄 \\ Takaharu Nakazima Ryozi Araki Masao Koike
}

\section{緒 震}

著者の一人が胆汁より抽出した一種の鉄化合物 $\left(\mathrm{C}_{68}\right.$ $\mathrm{H}_{80} \mathrm{~N}_{9} \mathrm{O}_{18} \cdot \mathrm{S} \cdot \mathrm{Fe}$ ) は脂肪消化汇対して殆んど無関係 であつた。体つて著者等はこの物筫が胆汁の分泌汶対 して何等か関与するところがあるか否かを試みるため 飞動物（犬）を用いてその胆汁の分泌量の直接測定を 行つた。

その結果を第二報として報告する。

\section{測定方法及び予備実馱}

$10 \mathrm{~kg}$ 程度の同一の条件下に䋒い,7日間を過ぎた犬 を用い，食後 5 時間を経て十二指腸を開き輸胆管の開 口部汇於て細い硝子管を插入し，流出する胆汁を集め この量を測定した。

この操作炕於て導管を挿大した時より胆汁の流出は 盛え亿始まり，約 10 分特を経れば流出は殆えど此む。 その流出量及び流出状況は第一表の如くであつた。

第 I 表 阳汒分泌状況

\begin{tabular}{|c|c|c|c|c|}
\hline & \multicolumn{2}{|r|}{ 胆 } & 汒 & 量 \\
\hline & 犬 & No.1 & 犬 No.2 & 2 犬 No.3 \\
\hline $\begin{array}{l}\text { 処置後 } 10 \text { 分間 } \\
\text { に於ける胆汁量 }\end{array}$ & & 4.7 c.c. & 5.6 c.c. & 5.3 c.c. \\
\hline 其後の状況 & $\begin{array}{l}\text { 胆汒分 } \\
\text { <時久 }\end{array}$ & $\begin{array}{l}\text { 泌殆えぞ } \\
\text { 数滴を流 }\end{array}$ & な 同 左 & 同 左 \\
\hline
\end{tabular}

纱, 何等萝物的刺㦸を与えず, 単電球で加湜して 体湿の降下を防ぐのみで 5 〜 時間生命を保たしめ得 た。

而して何等の試験に伐用しない同程度の体重の犬数

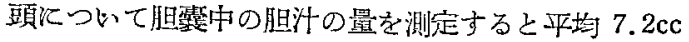
であつた。

以上の予借奏験により，著者等は本铁化合物其他の 試験品を導管を附して胖汁を流出させつつ 10 分時を
経過した犬の下肢に注射し，その後流出する㫜汁の量 を測定比較を行つた。その成綪を次項代記述する。

実 娩 成 綪

（1）本铁化合物注射火上る胆汁分泌試験

前項記載の如くにして胆汁を流出させつ」 10 分時 を経過しえ犬に本鉄化合物 $10 \mathrm{mg}$ を Ringer 氏液 10 c.c. K溶解したむのを反㻼注射し，その後の胆汁分必 の量を測定した。

その結果は第 2 表の如く、ですた。

5 分間を経過しても其の間灌か火 $0.25 \sim 0.32$ c.c. のみしか流出しない。而してこのまま測定を続けれ ば第1表に示した如く, 胆汁は㱠んど分泌されない筈 であるが，これに再び体鉄化合物を゙注射すれば最初の 5 分間任 102 113 c.c. を，次の 5 分聞比 $0.65 \sim 090$ c.c. を即ち 10 分間には 1,78 2.11 c.c. を分必した。 而して注射後 15 分を経過すれば胆汁の分䎵は多え と停止した。体つて第3 回の注射を行うえ又胆汁の分 泌を起し，5 分間隹 $0.46 \sim 0.52$ c.c. 10 分䦎以は 0.79 $\sim 0.85$ c.c. の分泌を見た。

以上の実験より本鉄化合物㤌乞の $10 \mathrm{mg}$ を注射す ることによつて一時的但汁の分泌を促す作用を有す ることを知つた。

第 1 図 $\mathrm{C}_{68} \mathrm{H}_{80} \mathrm{O}_{18} \mathrm{~N}_{9} \cdot \mathrm{S} \cdot \mathrm{Fe}$ 长よる胆汼分泌状況

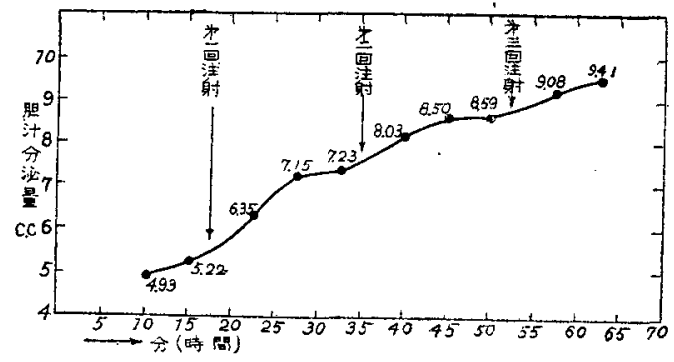




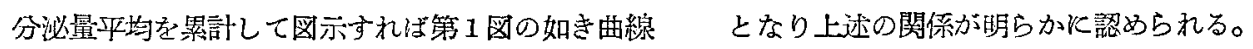

第 2 表 本鉄化合物飞よる胆汁分泌状況

\begin{tabular}{|c|c|c|c|c|c|c|c|}
\hline & & \multicolumn{3}{|c|}{ 胆 } & \multicolumn{3}{|c|}{ 量 } \\
\hline & & 犬 & No. 4 & 犬 & No. 5 & 犬 & No. 6 \\
\hline $\begin{array}{l}(1) \\
(2)\end{array}$ & $\begin{array}{l}\text { 処置後 } 10 \text { 分間に於沙る県汗量 } \\
\text { (1) 以後 } 5 \text { 分間の量 }\end{array}$ & & $\begin{array}{l}.5 .5 \text { c.c. } \\
0.25\end{array}$ & & $\begin{array}{l}4.8 \text { c.c. } \\
0.32\end{array}$ & & $\begin{array}{l}4.5 \text { c.c. } \\
0.30\end{array}$ \\
\hline $\begin{array}{l}(3) \\
(4) \\
(5)\end{array}$ & $\begin{array}{l}\mathrm{C}_{68} \mathrm{H}_{80} \mathrm{O}_{18} \mathrm{~N}_{9} \cdot \mathrm{S} \cdot \mathrm{Fe} \text { 注射後 } 5 \text { 分間の量 } \\
\text { (3) 以後の } 5 \text { 分問の量 } \\
\text { (4) 以後の } 5 \text { 分間の量 }\end{array}$ & & $\begin{array}{l}1.02 \\
0.90 \\
0.18\end{array}$ & & $\begin{array}{l}1.25 \\
0.86 \\
0.05\end{array}$ & & $\begin{array}{l}1.13 \\
0.65 \\
0.02\end{array}$ \\
\hline $\begin{array}{l}(6) \\
(7) \\
(8)\end{array}$ & $\begin{array}{l}\text { 第 } 2 \text { 回 } \mathrm{C}_{68} \mathrm{H}_{80} \mathrm{O}_{18} \mathrm{~N}_{9} \mathrm{~S} \cdot \mathrm{Fe} \text { 注射後 } 5 \text { 分間の量 } \\
\text { (6) 以後の } 5 \text { 分間の量 } \\
\text { その後の状況 }\end{array}$ & & $\begin{array}{l}0.85 \\
0.67 \\
\text { 何机 }\end{array}$ & 分 & $\begin{array}{l}0.82 \\
0.45 \\
\text { 泌殆え }\end{array}$ & $\%$ & $\begin{array}{l}0.74 \\
0.57 \\
2\end{array}$ \\
\hline $\begin{array}{l}(9) \\
(10) \\
(11)\end{array}$ & $\begin{array}{l}\text { 第 } 3 \text { 回 } \mathrm{C}_{68} \mathrm{H}_{80} \mathrm{O}_{18} \mathrm{~N}_{9} \mathrm{~S} \cdot \mathrm{Fe} \text { 注射後 } 5 \text { 分間の量 } \\
\text { (9) 以後の } 5 \text { 分間の量 } \\
\text { その後の状況 }\end{array}$ & & $\begin{array}{l}0.52 \\
0.33 \\
\text { 何れ }\end{array}$ & 分 & $\begin{array}{l}0.51 \\
0.28 \\
\text { 治 え }\end{array}$ & & $\begin{array}{l}0.46 \\
0.34 \\
\iota\end{array}$ \\
\hline
\end{tabular}

(2) コール酸ソーダ注射による胆汁分泌試験 ダを Ringer 氏液 10 c.c. に溶解したものを注射し， 前記と同栐に処置した犬に $10 \mathrm{mg}$ のコール酸ソー＼cjkstart胆汁の分泌量を測定した。(第3 表)

第 3 表 コール酸ッーダによる䐳汁分泌状況

\begin{tabular}{|c|c|c|c|c|c|c|c|}
\hline & & \multicolumn{3}{|c|}{ 㩐 } & \multicolumn{3}{|l|}{ 汁 } \\
\hline & & 犬 & No. 7 & 犬 & No. 8 & 犬 & No. 9 \\
\hline $\begin{array}{l}(1) \\
(2)\end{array}$ & 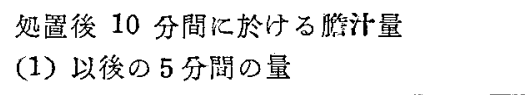 & & $\begin{array}{l}4.2 \text { c.c. } \\
0.14\end{array}$ & & $\begin{array}{l}4.6 \text { c.c. } \\
0.28\end{array}$ & & $\begin{array}{l}4.9 \text { c.c. } \\
0.25\end{array}$ \\
\hline $\begin{array}{l}(3) \\
(4) \\
(5)\end{array}$ & $\begin{array}{l}\text { ヌール酸ソーダ注射後 } 5 \text { 分間の量 } \\
\text { (3) 以後の } 5 \text { 分間の量 } \\
\text { (4) 以後の } 5 \text { 分間の量 }\end{array}$ & & $\begin{array}{l}0.39 \\
0.22 \\
0.05 \\
\end{array}$ & & $\begin{array}{l}0.38 \\
0.18 \\
0.07\end{array}$ & & $\begin{array}{l}0,32 \\
0.30 \\
0.0\end{array}$ \\
\hline $\begin{array}{l}(6) \\
(7) \\
(8)\end{array}$ & $\begin{array}{l}\text { 第 } 2 \text { 回コール酸ンーダ注射後 } 5 \text { 分間の量 } \\
\text { (6) 以後の } 5 \text { 分間の量 } \\
\text { その後の状況 }\end{array}$ & & $\begin{array}{l}0.12 \\
0.08 \\
\text { 何れ学 }\end{array}$ & & $\begin{array}{l}0.18 \\
0.05 \\
\text { 泌殆 } 九\end{array}$ & $な$ & $\begin{array}{l}0.25 \\
0.09 \\
L\end{array}$ \\
\hline $\begin{array}{l}(9) \\
(10) \\
(11)\end{array}$ & $\begin{array}{l}\text { 第 } 3 \text { 回コール酸ッーダ注射後 } 5 \text { 分間の量 } \\
\text { (9) 以後の } 5 \text { 分間の量 } \\
\text { その後の状況 }\end{array}$ & & $\begin{array}{l}0.08 \\
0.0 \\
\text { 何 水 }\end{array}$ & 分 & $\begin{array}{l}0.11 \\
0.06 \\
\text { 泌 殆 ん }\end{array}$ & & $\begin{array}{l}0.06 \\
0.02 \\
L\end{array}$ \\
\hline
\end{tabular}

以上の㐁硔に基いてこれを図示すると第 2 図の如き 曲線で示される。図で見られる如く本物質では注射後 の胆汁分必量の増量注認められるが本鉄化合物の如く 明膫でない。

（3）タウリン其他による胆汁分泌試験

(i) タウリン

上述の力法と全く同様にタウリン $10 \mathrm{mg}$ を注射し て試験したが胆汁は最初の分泌以後全く分泌を促がす と考兄られる現象を㒛めなかつた。
第 2 図 ムールンーダによる售汁分泌状況

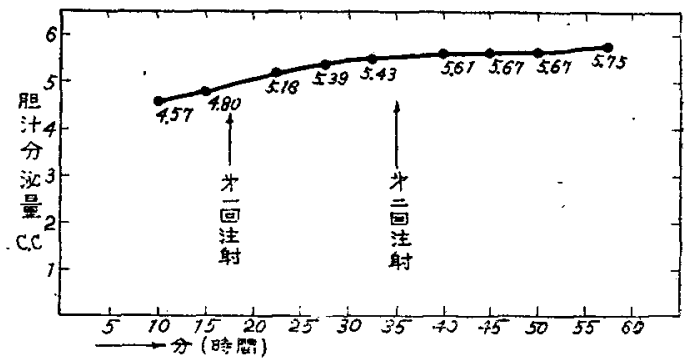


$-98-(350)$

(ii) ダウロコール酸ソーダ, ダリココール酸ソー $\not x$

この両者について全く同㥞のオ法で䏣汁分泌試駼を 行つた結是，僅かに作用があることを諗めたが，本鉄 北合物上比較すへくるなく、コ一ル酸ソーダよりも微 弱であつた。

即ち第 4 表 (A)，(B) 及第3 図曲線 (A)，(B)
炡した如くである。

而してタウロコール酸ソーダとグリコニール酸ソー ダと比較すると（第3図)，グリココール酸の作用が やや強く殆九どュール酸のそれと同様であるととが見 られる。

\section{実験結果の考察}

以上の実験により $\mathrm{C}_{6 \mathrm{~S}} \mathrm{H}_{\mathrm{S} 0} \mathrm{O}_{18} \mathrm{~N}_{9} \cdot \mathrm{S} \cdot \mathrm{Fe}$ の Ringer

第 4 表 タゥロコール酸ソーダ及びグリュコール酸ソーダによる脾汁分泌状沅

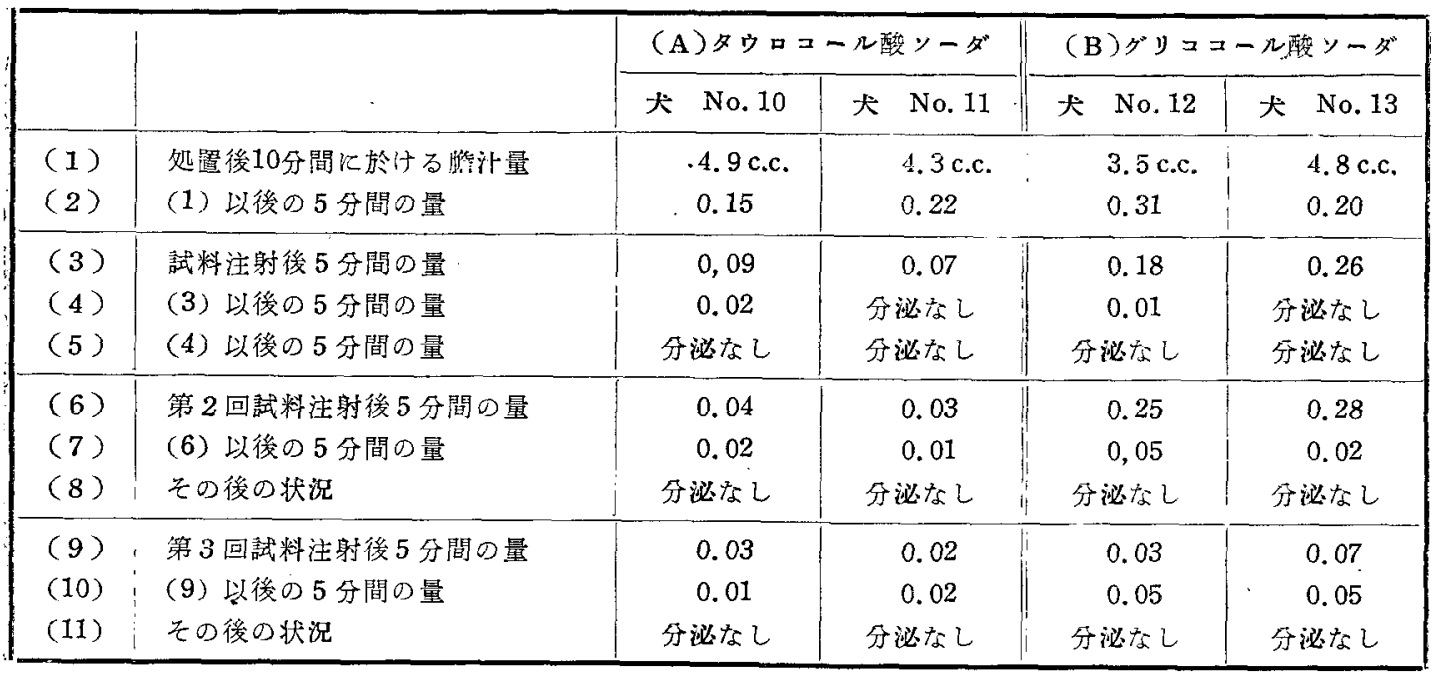

氏溶液は多少とも胆汁の分泌を促卞性貿を有する物質 であることを知つた。

即ち体重 $10 \mathrm{~kg}$ の犬の胆裂中にある全但汗量約 7

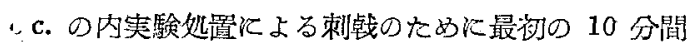
内江 5 c.c. 程度の分泌を見てしまうに毛拘らず,第1 注回射飞より約 2 c.c. を第 2 回注射飞より約 1.5 c.c. を更に第 3 回注射によつて約 1 c.c. 起分泌するのを見 t。

而してコール酸》ーダもこの作用を有するが，分泌 量から見れば本鉄化合物の $1 / 2$ 以下の能力を有するに 過ぎない。

又, タウロコール酸ソーダ,グリココール酸ソーダ そついて見るに両者之もコール酸よりも一層微弱であ るが,グリココール酸ソーががタウロコール酸ソーが そやや勝つて居るのは前者はコール酸りーダ（分子量 450) K対してグリココールの分子量小さく (75), 後 者はタウリンの分子量がグリココールに比してやや大 きい(125)ことも原因の一つと教られる。何礼机 してもコール酸ソーダ女びそのアミ，酸袮合体江比し て本铁化合物怯胆汁の分泌を促す作用を有することは 確寒でる。
第 3 図タゥロコール酸及びグリココール酸 による睢计分泌状況

$$
\begin{aligned}
& \text { ダウロコール酸ソーダ(突稿) } \\
& \text { ダリココール酸ソーダ(点線) }
\end{aligned}
$$

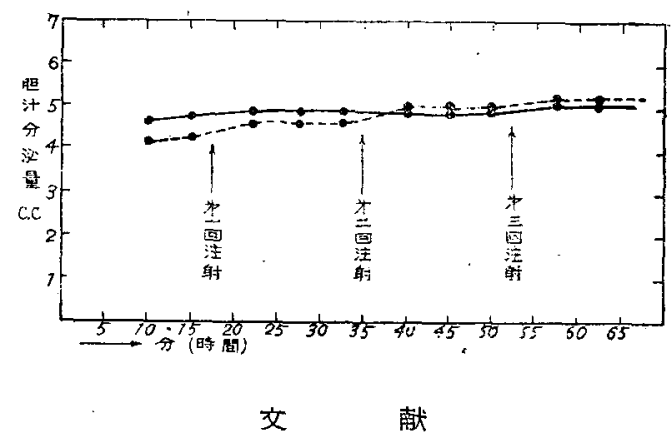

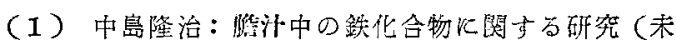
発表)

（2）中島隆治，島田政治，小池正雄：穊汁上り単離 せられた一種の欽化合物の医觉的作用について （第 1 報）日医大誌，21,94 (1954) 